\title{
The Relationship of Customer Perceived Risk and Customer Satisfaction
}

\section{Ali Ramezani Ghotbabadi}

\author{
Setareh Feiz \\ Rohaizat Baharun
}

Faculty of Management, Universiti Teknologi Malaysia (UTM), Skudai, Johor, Malaysia Email: zaosra@yahoo.com

\author{
Doi:10.5901/mjss.2016.v7n1s1p161
}

\begin{abstract}
This article aims to address the relationship between customer's Perceived Risk and customer's satisfaction. In industries with high competition like the Airline industry, it is vital to know the customers' needs, in order to satisfy, and to keep them loyal. Moreover, this article aims to present a strategy by deal with influence of relationship marketing, brand image, and service quality to decrease customer's perceived risk and increase customer satisfaction. Hypotheses are tested on questionnaire data on 776 passengers of Iranian airlines in an International Airport. The data was then analyzed by Structural Equation Modeling. The results indicate that service quality, relationship marketing, and brand image are related with customer's perceived risk. In addition, strong negative correlation has been found between the perceived risk and customer's satisfaction. The results are limited to airline industry and data collected from one international airport. More examples of researches from other industries and gathering data from larger population will help generalization of suggested model. Managers need improvement of service quality, relationship marketing, and brand image in order to decreasing the customer's perceived risk and increasing customer's satisfaction in order to improve the firm's profitability and performance. This study contributes to the knowledge by empirical study in customer's perceived risk and customer's satisfaction relationship. Moreover, proposing an applicable model to reduce perceived risk and increase the customer's satisfaction will help scholars and practitioners.
\end{abstract}

Keywords: Customer satisfaction, Perceived risk, Service quality, Relationship marketing, Brand image

\section{Introduction}

In today's market, factors of determining the corporate financial performance is not traditional indicators like size, economies of scale, or market share but corporate ability to continually improve the customer's satisfaction and retention of their customers (Hill et al., 2003). Thus, it is important for companies to increase their customer's satisfaction in order to increase the customer's future purchasing intention and gaining more profit for the company. Researchers and managers will mostly focused on the factors that increase the customer's satisfaction but there is also a negative side, which the managers also have to pay attention on the factors that can reduce the customer's satisfaction at the same time. Customer's perceived risk could be a threat for firms as it reduces the customer's satisfaction (An et al., 2010; Cunningham et al., 2002; Yoon \& Lee, 2014)

This research tries to suggest an integrated framework of reducing perceived risk and its effect on the customer's satisfaction. There is a lack of useful model for service firms, especially in the airlines industry in order to help them to avoid or reduce the customer's perceived risk and to increase the customer's satisfaction. This study is going to fill the gap in marketing management knowledge. Based on literature review, there are three major factors which are relationship marketing, brand image and service quality to reduce the perceived risk. The suggested model is useful for the researchers by proposing new model in consumer behavior knowledge. This study contributes to the knowledge by empirical study in customer's perceived risk and customer's satisfaction relationship. Moreover, proposing an applicable model to reduce perceived risk and increase the customer's satisfaction will help scholars and practitioners.

In the most researches regarding risk reduction, they only focused on limited factors and there is no an integrated framework. It is necessary to have a road map and clear implementation for managers to find the company's weaknesses, reduce the customer risk, and increase customer satisfaction. This study suggests an integrated framework include factors that applicable for companies and have significant effects on customer perceived risk and reducing its negative impact on customer satisfaction. This study improving our marketing knowledge in the customer perceived risk and customer satisfaction relationship. 


\section{Literature Review}

The twofold goal of marketing is to attract new customers by promising a superior value and to keep and grow current customers by delivering satisfaction (Armstrong \& Kotler, 2007). In response to the increment of global and competitive environment, companies keep searching for business practices that may lead them to a competitive advantage in the marketplace. Loyalty is predicted by a behavioral intent which is in turn seen as the customer's satisfaction (Ham, 2003). More researches had confirmed the positive relationship between the retention and profits (Bowen \& Chen, 2001).

\subsection{Customer Satisfaction}

Judgment of customers about the pleasurable level of improvement in needs, desires, and goals is by the consumption of a particular product or service, and defined as the customer's satisfaction (Oliver, 1999). Scientists believed that loyalty behaviors such as repurchase and word of mouth were mostly displayed by the satisfied customers (Taylor, 1998).

By using any approach or emphasis on satisfaction, the researchers have one common point, which is to understand the customer's needs and wants in order to develop the strength of the firm by using suitable strategies to increase the customer retention (Bao, 2009). Customer's satisfaction has massive influence on the loyalty behavior of customers, retention, and repurchase and it was considered as the main target of firms in order to improve their sale, profit and market share (Aldas-Manzano et al., 2011; Tuu et al., 2011).

Most researchers were looking for positive elements that can improve the customer's satisfaction but there is factor which has negative effect and able to reduce the customer's satisfaction (Bao, 2009). However, the positive impacts are so important, that the negative impacts can have their own threats to harm the customer's satisfaction. Firms have to consider both sides, positive and negative simultaneously. One of these threat factors is the customer's perceived risk. Furthermore, numerous researchers found that the customer's perceived risk significantly affects the decision making and evaluation process (Conchar et al., 2004). While the customer's satisfaction is the positive evaluation of performance, perceived risk is the negative evaluation that will lead to transaction avoidance of a product or service. Customer's perceived risk is important in the evaluation process of decision making and taking the risk of choosing a particular brand or paying for a product or service (Conchar et al., 2004). Moreover, previous studies found that perceived risk has high impact on the customer's satisfaction judgment (Habel \& Klarmann, 2014; Martin et al., 2015; Yongchang et al., 2011)

\subsection{Customer Perceived Risk}

Risk concept is significant to comprehend the customer's evaluating and decision making to choose a particular brand (Conchar et al., 2004). Perceived risk is so powerful in the customer behavior because customers are motivated to avoid making mistakes more than maximizing the purchasing utility (Mitchell, 1999). Risk perception and risk taking are a part of choice costs and it makes an important part of making a decision (Conchar et al., 2004). In 1960 for the first time, Bauer defined the perceived risk as "Perceived risk subjectively in a situation of making choice purchasing behavior "and various researchers followed him to refine, develop and expand it until today.

Definitions of risk showed that the risk perception is multidimensional and subjective. Conchar (2004) suggested that the customers to solidify their perception about the outcome, inherent, and importance of risk to confirm a subjective expectation of risk weight on alternatives over the mixed dimension of risks. Therefore, perceived risk is the important level of subjective estimation by customers about the inherent risks in alternatives for making choice.

Johnson, et al. (2008) had found two-sided correlation between the customer's satisfaction and perceived risk. They noted that perceived risk has influence on the customer's satisfaction and on the other hand, customer's satisfaction affects the customer's perceived risk in future transaction. Nevertheless, this research was evaluating just one side which is the effects of perceived risk on the customer's satisfaction. H8: There is a negative correlation between the customer's perceived risk and customer's satisfaction.

According to literature above, it is necessary for the companies to have strong strategy in reducing the customer's perceive risk and its negative effects towards the customer's satisfaction as it is the key factor in customer retention and company's performance.

\subsection{Relationship Marketing}

The relationship between the customers and firm will develop when there is benefit for both sides. Benefits of relationship with customers for firm will arise from the retention of customer to make future transactions (Reichheld \& Sasser, 1990) 
and insulation from the competition (E.W. Anderson \& Sullivan, 1993). Benefits of relationship with firm for customers contain customization and decreasing in cost and more efficiency by less cost of acquiring and reducing the risk (AlHersh et al., 2014). Many customers appeal to be in relationship with a particular brand for important services or products that they utilized. It can reduce the customer's risk perception and giving benefits for them. In services with high involvement, important, variability, and complexity, customers appeal to constantly stay in relationship with the trusted and same provider (Berry, 1995).

For more efficiency in choice behavior, reducing the processing of information, making stability decision, and reducing the risk of wrong choice, customers applied the strategy of relationship behavior with a particular brand (Sheth \& Parvatiyar, 1995). Close and long-term relationship between the customer and service or product provider will reduce the inherent of risk perception in the customer's purchasing behavior (Bataineh et al., 2015; Cheng \& Lee, 2011; Keith et al., 2004). Two hypotheses were concluded as: H3: There is a negative correlation between the relationship marketing and customer's perceived risk. H9: There is a correlation between the relationship marketing and customer's satisfaction by mediating the role of perceived risk.

\subsection{Service Quality}

Service quality is crucial for the performance and profitability of a firm. High quality of service will give competitive advantage to the firm in market by two ways, first by more attraction and acquiring new customers and second by retaining current customers by offering high quality and keeping them satisfied to repurchase even more in return which this way has less cost and more efficiency and profitability for the firms (Anderson et al., 1994). Researchers noted that the quality of service can affect customer's intention to purchase (Cronin et al., 2000).

Service quality can affect the customer's satisfaction directly and positively but it has a negative relationship with the perceived risk (Bicen, 2015; Chen \& Chang, 2005; Espejel et al., 2009). Researchers found that perceived risk can be controlled and reduced to avoid its harmful effects. Scientists found that one of the most effective elements in decreasing perceived risk is high quality of service (Espejel et al., 2009; Sun, 2014; Yongchang et al., 2011). Researchers claimed that the increment of service quality could effectively decrease the consumer's perceptions of risk (Cho et al., 2014). Two hypotheses concluded as: $\mathrm{H} 4$ : There is a negative correlation between the service quality and customer perceived risk. H11: There is a correlation between the service quality and customer's satisfaction by mediating the role of perceived risk.

\subsection{Brand Image}

In 1955, two researchers Gardner and Levy suggested the brand image theory. They noted that brands are not just physical meaning, but it has the psychological and social meaning as well, which concerns about the customer's behavior in decision making of choice between the alternatives (East et al., 2008). In 1988, Bennett clarified some factors for brand as name, design, symbol, sign, term, or a combination of these factors which can recognize the product or service of a particular provider. Some other terms suggested the brand image such as "the symbols by which we buy", "brand personality", and "brand meaning" (East et al., 2008).

It is formed as a result of the consumer's brand belief, which can be created by the marketer, formed by the consumer themselves through direct experience with the product, and/or formed by the consumer through inferences based on existing associations (Aaker, 1991). Concept of brand image make an attitude in customer's mind that associated with other factors like brand associations and brand attitude to make an integrate framework as brand equity (Agarwal \& Rao, 1996; Feldwick, 1996). Keller defined brand image as: "Perceptions about a brand as reflected by the brand associations held in consumer memory" (Keller, 1993, p. 3).

In service industry, customer value was created with positive interaction relationship between the customers and service providers by marketing activities. Associations of brand image are emotional perception of customers about the brand and deliver a symbolic meaning of product or service attributes. Integration of functional and symbolic attitude of a brand will influence overall believe of customers about the brand. Brand image in customer's mind made by the evaluation of customer about the brand and benefitting the information acquired through marketing activities (Brodie et al., 2009).

Researchers found a significant negative relationship between the brand image and perceived risk (Lin et al., 2011; Wang, 2015). Consumer research literature suggested that the consumers to use a brand name and store name to refine their purchasing choices and reduce risk (Aghekyan, 2009; Wu et al., 2011). Researchers have shown that a product's brand name can reduce the consumers' perceived risk (Aghekyan-Simonian et al., 2012; Huang et al., 2004; Kanbir \& 
Nart, 2009).

Every customer evaluates the attributes of a product or service in order to ease the decision in making a transaction. One of the most effective variables that lead the customers to select a particular brand is the brand image. Perceived risk is significant in evaluation process of customers about a brand, in which a positive brand image may reduce the negative effects of perceived risk. Two hypotheses concluded as: H5: There is a negative correlation between the brand image and customer's perceived risk. H10: There is a correlation between the brand image and customer's satisfaction by mediating the role of perceived risk.

Researchers believe that one of the most important factors in enhancing the perspective of customers to make a better brand image is having a good and long-term relationship with the customers. Relationship marketing has a direct effect on brand image and should be used as an effective tool in order to increase the brand image, customer retention and satisfaction by firms (Hashemi, 2012; Vegholm, 2011). Relationship marketing and having a long term relationship with the customers have strong, positive, and direct influence on brand image (Chen \& Chen, 2013). Two Hypotheses concluded as: H1: There is a positive correlation between the relationship marketing and brand image. H6: There is a correlation between the relationship marketing and perceived risk by mediating role of brand image.

Brand image comes from all experience of customer's consumption and service quality is the foundation for all consumption by customers. As a result, customer's service quality perception may have a high influence of brand image in customer's mind (Ahmadinejad et al., 2014; Aydin \& Özer, 2005). Some other researchers studied on this relationship and support the influence of service quality on the brand image (Elgin \& Nedunchezhian, 2012; Li \& Krit, 2012; Manhas \& Tukamushaba, 2015). Two hypotheses concluded as: H2: There is a positive correlation between the service quality and brand image. $\mathrm{H} 7$ : There is a correlation between the service quality and perceived risk by mediating the role of brand image.

\section{Conceptual Framework}

Based on above literature, this study evaluates relationship between the customer's perceived risk and satisfaction. The purpose of this study is to evaluate effective factors to reduce the customer's perceived risk in order to increase customer's satisfaction. Literature review indicates that variables such as relationship marketing, service quality, and brand image are the most effective in reducing customer's perceived risk.

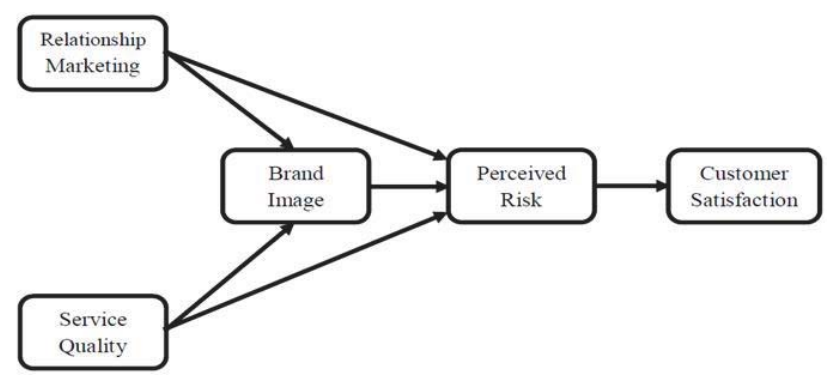

Figure 1: Conceptual framework

\section{Research Instruments}

The instruments used in this study were chosen based on prior studies. All the measurements are well established and developed by the experts in their field which gave the face validity to the instruments. The questionnaire method has been chosen for data collection as it is the best method for quantitative and statistical analysis. The variables measured by the separate parts contain several questions that suggested and tested by prior scientists for each variable. Current study adopts and applies the 7 point Likert scale for measuring the variables as one of the most instrumental and applicable scales in marketing research (Hayes, 2008; Sekaran, 1992).

\subsection{Customer Satisfaction Measurement}

In current study, we use the customer's satisfaction method based on airline industry that was established and used by 
prior researchers. We adopt the instruments used by prior studies (Bao, 2009; Cunningham et al., 2002; Oyewole et al., 2007) in airlines industry which include five items.

\subsection{Perceived Risk Measurement}

Factors selected to measure the risk that often used are the financial, physical, physiological, performance, and social risk that were suggested by Jacoby and Kaplan (1972) and time risk that was suggested by Roselius (1971) and Stone and Gronhaug (1993). For measuring these six factors, we choose 18 items which were collected from prior researches on perceived risk such as Jacoby and Kaplan (1972), Stone and Gronhaug (1993), Cunningham et al. (2004), (Laroche et al., 2004), and Espejel et al. (2009).

\subsection{Relationship Marketing Measurement}

In current study, we adopt four major dimensions for measuring relationship marketing based on Morgan and Hunt (1994). These four dimensions are trust, communication, commitment, and conflict management which were used and tested by previous researchers (Cheng \& Lee, 2011; Ndubisi, 2007) for measuring the relationship marketing from consumers' perspective.

\subsection{Brand Image Measurement}

Selected items related to airline industry were chosen for measuring the brand image based on previous studies (Aaker, 1997; Brodie et al., 2009). Five main factors determine an airline brand image were collected from Aaker study, which are friendly, spirited, up to date, reliable, successful, and confident.

\subsection{Service Quality Measurement}

Service quality measurement based on performance only, used in this study is a specific model for measuring the service quality in airlines that was suggested and tested by prior researches in airline industry (Cunningham et al., 2002; Kuo, 2011; Liou \& Tzeng, 2007; Tsaur et al., 2002). Dimensions and items suggested in this model are based on the airline industry. Service quality is divided into 4 dimensions (Employee service, Safety and Reliability, On-Board service, and Schedule and performance) with 14 items.

\section{Research Methodology}

This study has minimal interferences of researcher and studying events as they normally occur. In this research, as its nature which is correlational study, we try to evaluate the factors in real world without changing them to get sufficient and useful result.

\subsection{Reliability}

Cronbach's coefficient alpha is the most popular test of consistency reliability was used by the scholars. All the instruments including customer's satisfaction, perceived risk, relationship marketing, brand image, and service quality were examined by Cronbach's alpha. First, the pilot testing is conducted to test the internal consistency reliability of instruments. Collected questionnaires are applied for the Cronbach's alpha and those items which less than 0.7 are considered as unacceptable and those above 0.8 are considered as reliable instruments. Internal consistency reliability of items are measured by the Cronbach's alpha and obtained results. The result indicates good reliability of all instruments. Therefore, Cronbach's alpha of all instruments is above 0.8 and has excellent consistency of reliability. This coefficient indicates to what extent this measurement tools can accurately measure the dependent and independent variables.

Table 1: Reliability statistics

\begin{tabular}{|l|c|c|}
\hline & Cronbach's Alpha & N of Items \\
\hline Service Quality & 0.915 & 13 \\
\hline Relationship Marketing & 0.935 & 12 \\
\hline
\end{tabular}




\begin{tabular}{|l|c|c|}
\hline Brand Image & 0.886 & 5 \\
\hline Customer Perceived Risk & 0.949 & 18 \\
\hline Customer Satisfaction & 0.945 & 5 \\
\hline
\end{tabular}

\subsection{Sampling}

The sample size needs are based on proportionate stratified random sampling which involved 768 individual air travelers of three major Iranian Airlines. 768 respondents are the minimum number we must have for sampling. To improve the representativeness of samples, 800 passengers were selected and questionnaires were distributed between among them to achieve the minimum needed sample or above. Seven hundred and seventy six (776) questionnaires were collected from the passengers of three major Iranian airlines which are Mahan airlines, Iran Air, and Aseman Airlines in Shiraz International Airport.

\subsection{Data Analysis}

The method for this study is quantitative and the data is coded and analyzed numerically. The SEM technique by Lisrel 8.8 is used to examining the suggested models and the relationship among variables

\subsection{Evaluating the suitability of the data by Factor analysis}

For all three group of questions, Kaiser-Meyer-Olkin (KMO) index and Bartlett's test has been applied (Table 3). These indexes represent the suitability of data for doing factor analysis by using correlations. The value of KMO index is between 0 and 1 in which closer value to 1 shows more suitability for factor analysis. Factor analysis does not suitable for the values below 0.5 .

The Kaiser-Meyer-Olkin measure of sampling adequacy (KMO-test) was employed to check whether the sample is big enough. The sample is adequate if the KMO value is greater than 0.5 (Field, 2000). The results of each scale showed an adequate KMO value. Bartlett's test was used for each scale to check the inter-correlation that "tests the null hypothesis to prove that the original correlation matrix is an identity matrix" (Field, 2000p. 457). The result of KMO index and Bartlett's test indicated the adequate sample size for all groups of questions.

Table 2: KMO and Bartlett's test

\begin{tabular}{|c|c|c|c|}
\hline \multirow{4}{*}{ Service Quality } & \multicolumn{2}{|c|}{ Kaiser-Meyer-Olkin Measure of Sampling Adequacy } & 0.910 \\
\hline & \multirow{3}{*}{ Bartlett's Test of Sphericity } & Approx. Chi-Square & 5703.789 \\
\hline & & $\mathrm{df}$ & 78 \\
\hline & & Sig. & 0.000 \\
\hline \multirow{4}{*}{ Relationship Marketing } & \multicolumn{2}{|c|}{ Kaiser-Meyer-Olkin Measure of Sampling Adequacy } & 0.930 \\
\hline & \multirow{3}{*}{ Bartlett's Test of Sphericity } & Approx. Chi-Square & 6339.159 \\
\hline & & $\mathrm{df}$ & 66 \\
\hline & & Sig. & 0.000 \\
\hline \multirow{4}{*}{ Brand Image } & \multicolumn{2}{|c|}{ Kaiser-Meyer-Olkin Measure of Sampling Adequacy } & .871 \\
\hline & \multirow{3}{*}{ Bartlett's Test of Sphericity } & Approx. Chi-Square & 2232.471 \\
\hline & & df & 10 \\
\hline & & Sig. & 0.000 \\
\hline \multirow{4}{*}{ Customer Perceived Risk } & \multicolumn{2}{|c|}{ Kaiser-Meyer-Olkin Measure of Sampling Adequacy } & 0.934 \\
\hline & \multirow{3}{*}{ Bartlett's Test of Sphericity } & Approx. Chi-Square & 12418.389 \\
\hline & & $\mathrm{df}$ & 153 \\
\hline & & Sig. & 0.000 \\
\hline \multirow{4}{*}{ Customer Satisfaction } & \multicolumn{2}{|c|}{ Kaiser-Meyer-Olkin Measure of Sampling Adequacy } & 0.887 \\
\hline & \multirow{3}{*}{ Bartlett's Test of Sphericity } & Approx. Chi-Square & 3721.139 \\
\hline & & $\mathrm{df}$ & 10 \\
\hline & & Sig. & 0.000 \\
\hline
\end{tabular}




\subsection{Validity}

In current study, factor analysis conducted to test the construct validity of instruments. Confirmatory Factor Analysis (CFA) is applied to test the construct validity of relationship marketing, brand image, service quality, perceived risk, and customer satisfaction in this study.

Taking sample sensitivity and model complexity effects into account, NFI (Normed Fit Index), IFI (Incremental Fit Index), TLI (NNFI- Non-Normed Fit Index), CFI (Comparative Fit Index), and RMSEA are chosen in this study for evaluating fit indices. Root Mean Square Error of Approximation (RMSEA) indicates how well the proposed interrelationships between the variables match the interrelationships between the actual or observed interrelationships.

All items for Service Quality measurement have an acceptable score by CFA. In the standard estimation of relationship marketing measurement, all fit indices were acceptable except the RMSEA with the measurement 0.108. As a result, this measurement needs further analysis and modifications. By removing item 7 from the communication dimension of relationship marketing variable, the RMSEA was improved by 0.069 which is reasonable and approve the measurement thus making it acceptable. Confirmatory factor analysis has been done on the brand image items and the result showed all 5 items can be used. The standard estimation by confirmatory factor analysis on the main mediator, perceived risk shows an acceptable result. All items are accepted by factor analysis by good scores. Customer's satisfaction as the main dependent variable that consumes 5 items in its measurement. By standard estimation of this measurement, we got poor result for RMSEA by 0.182 which needs further analysis and modification. By further analysis and removing item 1, the result improved. After modification, the RMSEA improved to 0.036 which is excellent for overall fit indices and accepted result. As a result, we used 4 items for measurement of this variable.

Table 3: Measurement fit indices

\begin{tabular}{|c|c|c|c|c|c|}
\hline & Service Quality & Relationship Marketing & Brand Image & Perceived Risk & Customer Satisfaction \\
\hline NFI & 0.97 & 0.99 & 0.99 & 0.98 & 1 \\
\hline TLI (NNFI) & 0.97 & 0.98 & 0.99 & 0.98 & 1 \\
\hline IFI & 0.98 & 0.98 & 0.99 & 0.98 & 1 \\
\hline CFI & 0.98 & 0.99 & 0.98 & 0.98 & 1 \\
\hline RMSEA & 0.080 & 0.069 & 0.068 & 0.073 & 0.036 \\
\hline
\end{tabular}

As a result of measurement fit indices shown in table 5, all instruments are accepted using SEM evaluation and analysis. Modifications on the measurements and their items were applied. Measurements appeared to be accepted items are 13 items for service quality measurement, relationship marketing with 11 items after modifying and removing one item from this instrument, brand image with 5 items, perceived risk with 18 items, and customer satisfaction as the dependent variable of this study with 4 items after modifying and removing one item which significantly improved the fit indices of this instrument.

\section{Result}

The p-value obtained for model of this study is 0.000 which is highly acceptable. The values of fit indices measured in Lisrel indicated the acceptable fit of proposed model as below:

$\mathrm{NFI}=0.94, \mathrm{TLI}=0.95, \mathrm{IFI}=0.95, \mathrm{CFI}=0.95, \mathrm{RMSEA}=0.068$

T-value of Variables Relationship

On figure 2, the T-value for structural equation of model was obtained. Significantly, the T-value of all relationship between variables was accepted. 


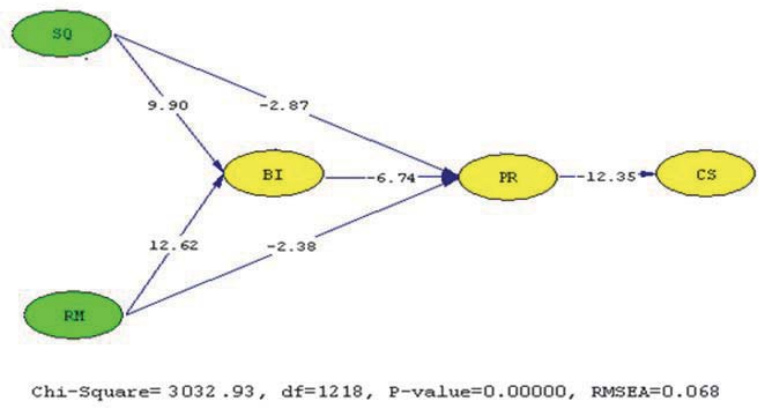

Figure 2: Structural equation model with T-value

\subsection{Standard Solution}

Standard coefficient is the correlation between two variables. The purpose of standard coefficient is to measure the effects of model components. So, as this coefficient is getting higher, the correlation and effect of independent variable is also getting higher on the dependent variable. Figure 3 is the standard solution of structural equation modeling with acceptable p-value, RMSEA, df, and Chi-Square.

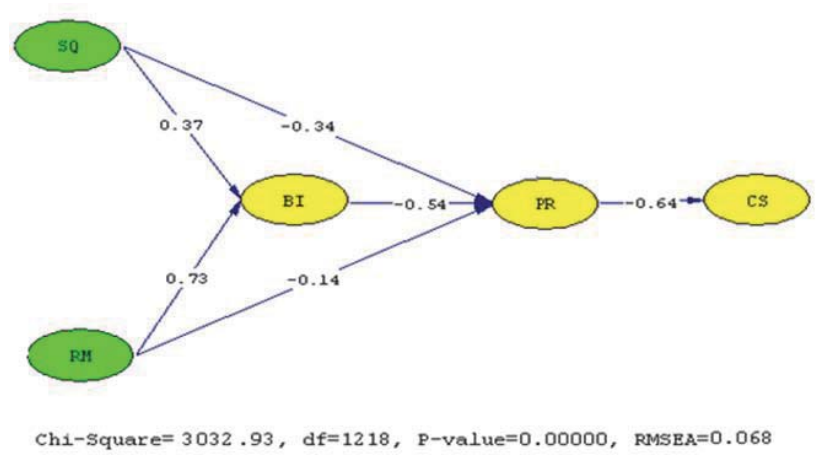

Figure 3: Standardized structural equation modeling (standard solution)

Table 6 shows the T-value and standardized coefficients $(\beta)$ value obtained in structural equation modeling for each relationship in model.

Table 6: T-value and $\beta$ of structural equation model

\begin{tabular}{|l|c|c|}
\hline Relationships & T-value & Standardized $\beta$ \\
\hline Service Quality $\rightarrow$ Brand Image & 9.9 & 0.37 \\
\hline Service Quality $\rightarrow$ Perceive Risk & -2.87 & -0.34 \\
\hline Relationship Marketing $\rightarrow$ Brand Image & 12.62 & 0.73 \\
\hline Relationship Marketing $\rightarrow-\rightarrow$ Perceived Risk & -2.38 & -0.14 \\
\hline Brand Image $\rightarrow$ Perceived Risk & -6.74 & -0.54 \\
\hline Perceived Risk $\rightarrow-\rightarrow$ Customer Satisfaction & -12.35 & -0.64 \\
\hline Note: All results supported at significance level: $p<0.05$ & & \\
\hline
\end{tabular}

Correlation between variables was accepted in all suggested path. The whole model was accepted and all of hypothesizes and paths in suggested model was approved. 
Table 7: Summary of hypothesis

\begin{tabular}{|c|c|c|c|}
\hline Hypothesis & Hypothesis Path & Path Coefficient & Result \\
\hline $\mathrm{H} 1$ & $\mathrm{RM}^{(\mathrm{a})} \boldsymbol{\longrightarrow} \rightarrow \mathrm{Bl}^{(\mathrm{b})}$ & 0.73 & Accepted \\
\hline $\mathrm{H} 2$ & $\mathrm{SQ}^{(\mathrm{c})} \boldsymbol{x} \boldsymbol{\longrightarrow B \mathrm { BI }}$ & 0.37 & Accepted \\
\hline $\mathrm{H} 3$ & $\mathrm{RM} \leadsto \mathrm{PR}^{(\mathrm{d})}$ & -0.14 & Accepted \\
\hline $\mathrm{H} 4$ & $\mathrm{SQ}-\rightarrow \mathrm{PR}$ & -0.34 & Accepted \\
\hline $\mathrm{H} 5$ & $\mathrm{Bl} \rightarrow \mathrm{PR}$ & -0.54 & Accepted \\
\hline $\mathrm{H} 6$ & $\mathrm{RM}-\boldsymbol{B}-\boldsymbol{B}-\boldsymbol{M P R}$ & $(0.73) *(-0.54)$ & Accepted \\
\hline $\mathrm{H} 7$ & $\mathrm{SQ}-\rightarrow \mathrm{Bl} \rightarrow \mathrm{PR}$ & $(0.37) *(-0.54)$ & Accepted \\
\hline $\mathrm{H} 8$ & 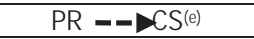 & -0.64 & Accepted \\
\hline $\mathrm{H} 9$ & $\mathrm{RM}=\boldsymbol{A P R} \boldsymbol{C} \rightarrow \mathrm{CS}$ & $(-0.14) *(-0.64)$ & Accepted \\
\hline $\mathrm{H} 10$ & $\mathrm{Bl}=\boldsymbol{M} \rightarrow \mathrm{PR}=\boldsymbol{C S S}$ & $(-0.54) *(-0.64)$ & Accepted \\
\hline H11 & $\mathrm{SQ}=\boldsymbol{M P R}-\boldsymbol{C S}$ & $(-0.34) *(-0.64)$ & Accepted \\
\hline
\end{tabular}

(a): Relationship Marketing, (b): Brand Image, (c): Service Quality, (d): Customer Perceived Risk, (e): Customer Satisfaction

Note: All results supported at significance level: $p<0.05$

\section{Implications}

\subsection{Theoretical Implications}

The present study suggests some implications for the researchers and added values to the body of knowledge. First, there is direct and indirect correlation of service quality and relationship marketing with perceived risk but, the indirect effect is much higher than direct effect. Service quality and relationship marketing could more effectively influence the perceived risk through mediating the role of brand image. Moreover, brand image itself has a strong effect on perceived risk. A convened of service quality, relationship marketing, and brand image by their synergistic effect can be more effective to reduce customer's perceived risk.

Second, direct effect of perceived risk on customer's satisfaction was suggested. Perceived risk could strongly influence the customer's satisfaction and as a result, decision making for future purchase can easily be made. Customer's satisfaction is the key factor in customer retention to repurchase and contribute to organization's profit (Etgar \& Fuchs, 2009; Trasorras, 2008). By increasing the burden of loss and risk, customer may tend to use the alternatives. Decreasing the burden of loss and risk when using a particular service/product may lead the customers to experience satisfaction and creating the intention to repurchase.

Third, findings indicated by decreasing perceived risk, the customer's satisfaction will increase and the customers will have more intention to repurchase. Therefore, decreasing the customer's perceived risk could be an effective way to achieve the customer's satisfaction. The main goal of this study is to find a way to improve the customer's satisfaction. Correlation of perceived risk on the customer's satisfaction is negatively at a high level. The present study suggests an integrated and comprehensive model to increase the customer's satisfaction. Integrated model was suggested to evaluate the service quality, relationship marketing, brand image and their influence on the perceived risk simultaneously by affecting the customer's satisfaction. Three factors of service which are quality, relationship marketing, and brand image were found as the major factors which effectively influence the perceived risk. Negative correlation of these factors with perceived risk shows that the customer's perceived risk will dramatically decrease by the increment in the quality of service, relationship marketing, and brand image in the customer's thought. This model is a new and effective one in perceived risk and customer's satisfaction field.

\subsection{Managerial Implications}

Although there has been numerous amount of studies conducted on the customer's satisfaction, this research confirmed the fundamental finding as a model for customer's perceived risk and satisfaction relationship by including improvements in the structural model.

First, the results indicate that direct correlation of service quality and relationship marketing on perceived risk is not as strong as we expected but the indirect effect of them by mediating the role of brand image is much stronger. This suggests that there is considerable room for improvement in the brand image by service quality, relationship marketing 
and any other effective factors to reduce perceived risk. Management should attend in service quality and relationship marketing implementation system and the employees must engage their attention into a quality and customer-oriented activities. In particular, the findings strongly suggested that implementation of quality services and relationship marketing toward improvement of brand image has a negative effect on the customer's perceived risk. Therefore, managers need to evaluate the service quality, relationship marketing, and brand image altogether in order to reduce customer's perceived risk.

Second, managers should be aware of the importance of customer's perceived risk through the customer's satisfaction and its' effect upon the company's profitability. Customer's satisfaction can lead them to have retention to purchase and hand more profit for the firms. The key element to increase customer's satisfaction is reducing the customer's perceived risk and obtaining the trust and significance of customers. A group of factors, namely the service quality, relationship marketing, and brand image is effective to make it happen. The synergistic power of these factors enables the firm to obtain trust and significance of customers about a particular service/product and reducing the chance of risk in customer's thoughts. Negative correlation of these factors with perceived risk shows that customer's perceived risk will dramatically decrease by increasing the quality of service/product and relationship with customers besides increasing the image of brand in customer's thoughts. Thus, the managers must apply a group of activities to reduce the customer's perceived risk. Managers need improvement of service quality, relationship marketing, and brand image in order to decreasing the customer's perceived risk and increasing customer's satisfaction in order to improve the firm's performance.

Third, this study focused on the airline industry, but discussions and results about suggested model are applicable to other industries as well. The findings suggest that majority of the key issues, problems, and solutions are relevant across various industries. Therefore, managers need to pay greater attention to different aspects of variables in each industry. The measurement, dimensions, aspects of quality, relationship marketing, brand image, perceived risk, and customer satisfaction may differ across different industries or in same industry, but in different countries. Managers could use this model with suitable components for their industries to maximize the satisfaction of their customers.

\section{Limitations of the Research}

Although this study produced interesting and meaningful findings, there were some limitations that need to be discussed. The limitations of the research are essential for an assessment of validity of the research (Kinnear \& Taylor, 1996). This research limited to airline industry and data collected from one international airport. More examples of researches from other industries and gathering data from larger population will help generalization of suggested model.

\section{Directions for Further Research}

Based on the limitations identified within this study and a solid foundation of the current study was established, a number of suggestions for possible aspects for further research were brought up. To further this field of research and evaluate the generalized ability of the results, it may be beneficial to repeat the existing studies and amend the industry right away. The replications of this study in different countries or other industries are necessary as well.

Moreover, it is crucial for both customer and manager oriented to adapt this model as it could help organizations to improve their products and services and even to increase the customer's satisfaction in order to gain economic profitability. There is a need to investigate further for better understanding on the impact of both manager's and customer's perspective on these relationships. Thus, by a little change in the dimensions of this study's variables, it is possible to perform this finding for the manager's perspective in future researches. Also, investigating both views can create a new study with a comparative power.

\section{Conclusion}

This research was conducted as a result by the discovery of the customers' view regarding the quality of service, relationship marketing activities, image of brand, perceived risk, and the influence on their satisfaction. The focus of this study was to determine how firms can reduce customer's perceived risk if perceived risk has negative impact on the customer's satisfaction. The influence of perceived risk on satisfaction was investigated. In addition, the influence of three major factors which are service quality, relationship marketing, and brand image on perceived risk and customer's satisfaction was also investigated.

This research has significantly found a direct influence of customer's perceived risk on the customer's satisfaction 
in airline industry. Results indicated that the negative correlation of service quality, relationship marketing, and brand image with the perceived risk. This study also confirmed the significant relationship of service quality, relationship marketing, and brand image with the customer's satisfaction by mediating the customer's perceived risk. In addition, service quality and relationship marketing were found as the factors which could influence the brand image in customer's thoughts. Vital issues regarding variable measurements were addressed and clarified in this study. This research also highlighted significant issues which relevant to the performed model.

Literature review and the results indicated that the service quality has influence on brand image. On the other hand, relationship marketing is considered as a new concept in marketing and was found to have strong influence on the brand image. In order to increase the brand image which is important to increase the customer's trust, firms have to reasonably increase the quality of their services and relationship marketing activities. By increasing these two factors, the brand image will be increased and if these factors were decreased, the brand image will be failed in the customer's thoughts. Regarding the findings of this study, group of these three variables were found to be an effective tool in reducing the customer's perceived risk. Customers always evaluate the performance of services they received and compared them with the alternatives. As a result, perceived risk has important role in future transaction. This study found the meaningful negative correlation of three major factors which are the service quality, relationship marketing, and brand image with perceived risk. By reducing these factors, the perceived risk will increase and increasing these factors would be effective to reduce the customer's perceived risk. The results showed that greater service quality, relationship marketing, and brand image could improve the customer's satisfaction and consequently creates retention for the customers to make transactions in future.

In a nutshell, this study is the important mediational role of customer's perceived risk. Iran airlines can improve their business performance by achieving the satisfaction of their customers. Improving the quality of their services, creating useful relationships with customers by marketing activities, and finally developing their brand image is the crucial for the Iranian airlines to reduce the customer's perceived risk and to increase the customer's satisfaction. Literature showed that customer's satisfaction has a high correlation with customer's retention. So the airlines are aware enough that the customer's retention is easier and cheaper than acquiring new customers. They should care more to satisfy and retain acquired customers and then continue the relationship with retained customers.

\section{References}

Aaker, D. A. (1991). Managing Brand Equity (1st ed.): Free Press.

Aaker, J. L. (1997). Dimensions of brand personality. Journal of Marketing Research, 34(3), 347-356.

Agarwal, M. K., \& Rao, V. R. (1996). An Empirical Comparison of Consumer-Based Measures of Brand Equity. Marketing Letters, 7(3), 237-247.

Aghekyan-Simonian, M., Forsythe, S., Suk Kwon, W., \& Chattaraman, V. (2012). The role of product brand image and online store image on perceived risks and online purchase intentions for apparel. Journal of Retailing and Consumer Services, 19(3), 325331.

Aghekyan, M. (2009). The role of product brand image and online store image on perceived risk and online purchase intentions. (Degree of Doctor of Philosophy), Auburn, Alabama.

Ahmadinejad, B., Karampour, A., \& Nazari, Y. (2014). A survey on interactive effect of brand image and perceived quality of service on each other; (case study: Etka chain stores). Kuwait Chapter of the Arabian Journal of Business and Management Review, 3(8), 217-224.

Al-Hersh, A. M., Aburoub, A. t. S., \& Saaty, A. S. (2014). The Impact of Customer Relationship Marketing on Customer Satisfaction of the Arab Bank Services. International Journal of Academic Research in Business and Social Sciences, 4(5), 67-100.

Aldas-Manzano, J., Ruiz-Mafe, C., Sanz-Blas, S., \& Lassala-Navarre, C. (2011). Internet banking loyalty: evaluating the role of trust, satisfaction, perceived risk and frequency of use. Service Industries Journal, 31(7), 1165-1190.

An, M., Lee, C., \& Noh, Y. (2010). Risk factors at the travel destination: their impact on air travel satisfaction and repurchase intention. Service Business 4(2), 155-166. doi: 10.1007/s11628-010-0094-2

Anderson, E. W., Fornell, C., \& Lehmann, D. R. (1994). Customer satisfaction, market share, and profitability - Finding from Sweden Journal of Marketing, 58(3), 53-66.

Anderson, E. W., \& Sullivan, M. W. (1993). The Antecedents and Consequences of Customer Satisfaction for Firms. Marketing Science, 12(2), 125-143.

Armstrong, G., \& Kotler, P. (2007). Marketing: An Introduction (8 ed.): Pearson Prentice Hall.

Aydin, S., \& Özer, G. (2005). The analysis of antecedents of customer loyalty in the Turkish mobile telecommunication market. European Journal of Marketing, 39(7), 910-925.

Bao, B. C. (2009). Air travel in the U.S: An investigation of the influence of perceived risk in service quality. (Doctor of Philosophy), Capella University.

Bataineh, A. Q., Al-Abdallah, G. M., Salhab, H. A., \& Shoter, A. M. (2015). The Effect of Relationship Marketing on Customer Retention 
in the Jordanian's Pharmaceutical Sector. International Journal of Business and Management, 10(3), 117-131.

Berry, L. L. (1995). Relationship Marketing of Services-Growing Interest, Emerging Perspectives. Journal of the Academy of Marketing Science., 23(4), 236-245.

Bicen, P. (2015). Consumer Perceptions of Quality, Risk, and Value: A Conceptual Framework. In H. E. Spotts (Ed.), Revolution in Marketing: Market Driving Changes (pp. 1-1). London: Springer International Publishing.

Bowen, J. T., \& Chen, S.-L. (2001). The relationship between customer loyalty and customer satisfaction. International Journal of Contemporary Hospitality Management, Vol. 13(5), 213 - 217.

Brodie, R. J., Whittome, J. R. M., \& Brush, G. J. (2009). Investigating the service brand: A customer value perspective. Journal of Business Research, 62(3), 345-355.

Chen, T.-y., \& Chang, H.-S. (2005). Reducing Consumers' Perceived Risk through Banking Service Quality Cues in Taiwan. Journal of Business and Psychology, 19(4), 521-540.

Chen, W.-J., \& Chen, M.-L. (2013). Factors Affecting the Hotel's Service Quality: Relationship Marketing and Corporate Image. Journal of Hospitality Marketing \& Management, 23(1), 77-96.

Cheng, C. F., \& Lee, A. H. (2011). The influences of relationship marketing strategy and transaction cost on customer satisfaction, perceived risk, and customer loyalty. African Journal of Business Management, 5(13), 5199-5209.

Cho, M., Bonn, M. A., \& Kang, S. (2014). Wine attributes, perceived risk and online wine repurchase intention: The cross-level interaction effects of website quality. International Journal of Hospitality Management, 43(0), 108-120.

Conchar, M. P., Zinkhan, G. M., Peters, C., \& Olavarrieta, S. (2004). An integrated framework for the conceptualization of consumers' perceived-risk processing. Journal of the Academy of Marketing Science, 32(4), 418-436.

Cronin, J. J., Brady, M. K., \& Hult, G. T. M. (2000). Assessing the effects of quality, value, and customer satisfaction on consumer behavioral intentions in service environments. Journal of Retailing, 76(2), 193-218.

Cunningham, L. F., Young, C. E., \& Lee, M. (2004). Perceptions of Airline Service Quality: Pre and Post 9/11. Public Works Management \& Policy, 9(1), 10-25.

Cunningham, L. F., Young, C. E., \& Moonkyu, L. (2002). Cross- Cultural Perspectives of Service Quality and Risk in Air Transportation Journal of Air Transportation, 7(1), 3-26.

East, R., Wright, M., \& Vanhuele, M. (2008). Consumer Behaviour Application in Marketing (1st ed.). London: SAGE Publications Ltd.

Elgin, A., \& Nedunchezhian, V. R. (2012). An Analytical Study into the Effects of Service Quality on the Perception of Domestic Airline Image with Special Reference to Frequent Fliers at Trivandrum City in India. European Journal of Social Sciences, 29(4), 521527.

Espejel, J., Fandos, C., \& Flavián, C. (2009). The influence of consumer involvement on quality signals perception: An empirical investigation in the food sector. British Food Journal, 111(11), 1212-1236.

Etgar, M., \& Fuchs, G. (2009). Why and how service quality perceptions impact consumer responses. Managing Service Quality, 19(4), 474-485.

Feldwick, P. (1996). What is brand equity anyway, and how do you measure it? Journal of the Market Research Society, 38(2), 85-104.

Field, A. P. (2000). Discovering Statistics Using SPSS for Windows: Advanced Techniques for the Beginner (illustrated ed.). London: Thousand Oaks; New Delhi: Sage Publications.

Habel, J., \& Klarmann, M. (2014). Customer reactions to downsizing: when and how is satisfaction affected? Journal of the Academy of Marketing Science, 1-22.

Ham, C. L. (2003). Service quality, customer satisfaction, and customer behavioral intentions in higher education (Doctoral dissertation), Nova Southeastern University

Hashemi, T. N. (2012). The impact of customer relashionship marketing on customer's image for Jordanian five star hotels. International Journal of Business and Social Science, 3(2), 129-134.

Hayes, B. E. (2008). Measuring customer satisfaction and loyalty : survey design, use, and statistical analysis methods (3rd ed.). Milwaukee, Wis.: ASQ Quality Press.

Hill, N., Brierley, J., \& MacDougall, R. (2003). How to measure customer satisfaction (2nd ed.). Burlington, VT, USA: Gower.

Huang, W.-y., Schrank, H., \& Dubinsky, A. J. (2004). Effect of brand name on consumers' risk perceptions of online shopping. Journal of Consumer Behaviour, 4(1), 40-50.

Jacoby, J., \& Kaplan, L. B. (1972). The Components of perceived risk. In M. Venkatesan (Ed.), Advances in Consumer Research (pp. 382-393). Chicago: Association for consumer research.

Kanbir, H., \& Nart, S. (2009). Investigating drivers of choice behavior: Corporate image, perceived risk and reputation management. Journal of Global Strategic Management, 5, 121-134.

Keith, J. E., Lee, D.-J., \& Leem, R. G. (2004). The Effect of Relational Exchange Between the Service Provider and the Customer on the Customer's Perception of Value. Journal of Relationship Marketing, 3(1), 3-33.

Keller, K. L. (1993). Conceptualizing, Measuring, and Managing customer-based brand equity Journal of Marketing, 57(1), 1-22.

Kinnear, T. C., \& Taylor, J. R. (1996). Marketing Research: An Applied Approach (5th ed.). New York: McGraw-Hill.

Kuo, M.-S. (2011). A novel interval-valued fuzzy MCDM method for improving airlines' service quality in Chinese cross-strait airlines. Transportation Research Part E: Logistics and Transportation Review, 47(6), 1177-1193.

Laroche, M., McDougall, G. H. G., Bergeron, J., \& Yang, Z. (2004). Exploring How Intangibility Affects Perceived Risk. Journal of Service Research: JSR, 6(4), 373-389.

Li, X., \& Krit, J. (2012). Service Is Power: Exploring Service Quality in Hotel's Business, Yunnan, China. International Business 
Research, 5(5), 35-48.

Lin, T. Y., Yeh, R. C., Chung, P., Wen, L. R., \& Chen, S. J. (2011). Study of Product Brand Image and Individual's Product knowledge and Perceived Risk Affecting on Consumer Purchasing Behavior. Paper presented at the International Conference on Business And Information (BAI 2011), ISSN: 1729-9322, Bangkok, Thailand.

Liou, J. J. H., \& Tzeng, G.-H. (2007). A non-additive model for evaluating airline service quality. Journal of Air Transport Management, 13(3), 131-138.

Manhas, P. S., \& Tukamushaba, E. K. (2015). Understanding service experience and its impact on brand image in hospitality sector. International Journal of Hospitality Management, 45(0), 77-87.

Martin, J., Mortimer, G., \& Andrews, L. (2015). Re-examining online customer experience to include purchase frequency and perceived risk. Journal of Retailing and Consumer Services, 25(0), 81-95.

Mitchell, V.-W. (1999). Consumer perceived risk: conceptualisations and models. European Journal of Marketing, 33(1/2), 163-195.

Morgan, R. M., \& Hunt, S. D. (1994). The Commitment-Trust Theory of Relationship Marketing. The Journal of Marketing, 58(3), 20-38.

Ndubisi, N. O. (2007). Relationship marketing and customer loyalty. Marketing Intelligence \& Planning, 25(1), 98-106.

Oliver, R. L. (1999). Whence Consumer Loyalty? The Journal of Marketing, 63(Fundumental Issues and Directions for Marketing), $33-44$.

Oyewole, P., Sankaran, M., \& Choudhury, P. (2007). Marketing Airline Services in Malaysia: A Consumer Satisfaction Orientation Approach. Innovative Marketing, 3(1), 56-70.

Reichheld, F. F., \& Sasser, W. E. (1990). Zero defections - Quality comes to service Harvard Business Review, 68(5), $105-111$.

Roselius, T. (1971). Consumer Rankings of Risk Reduction Methods. Journal of Marketing, 35(1), 56-61.

Sekaran, U. (1992). Research methods for business : a skill-building approach (2nd ed.). New York: Wiley.

Sheth, J. N., \& Parvatiyar, A. (1995). Relationship Marketing in Consumer Markets: Antecedents and Consequences. Journal of the Academy of Marketing Science, 23(4), 255-271.

Stone, R. N., \& Gronhaug, K. (1993). Perceived Risk: Further Considerations for the Marketing Discipline. European Journal of Marketing, 27(3), 39-50.

Sun, J. (2014). How risky are services? An empirical investigation on the antecedents and consequences of perceived risk for hotel service. International Journal of Hospitality Management, 37(0), 171-179.

Taylor, T. B. (1998). Better loyalty measurement leads to business solutions. Marketing News, 32(22), 41-41.

Trasorras, R. J. (2008). The relationship of value, satisfaction and loyalty on customer retention in the professional service sector. (Doctor of Business Administration ), Nova Southeastern University.

Tsaur, S.-H., Chang, T.-Y., \& Yen, C.-H. (2002). The evaluation of airline service quality by fuzzy MCDM. Tourism Management, 23(2), 107-115. doi: 10.1016/S0261-5177(01)00050-4

Tuu, H. H., Olsen, S. O., \& Linh, P. T. T. (2011). The moderator effects of perceived risk, objective knowledge and certainty in the satisfaction-loyalty relationship. Journal of Consumer Marketing, 28(5), 363 - 375.

Vegholm, F. (2011). Relationship marketing and the management of corporate image in the bank-SME relationship. Management Research Review, 34(3), 325-336.

Wang, E. S.-T. (2015). Effect of food service-brand equity on consumer-perceived food value, physical risk, and brand preference. British Food Journal, 117(2), 553-564.

Wu, P. C. S., Yeh, G. Y. Y., \& Hsiao, C. R. (2011). The effect of store image and service quality on brand image and purchase intention for private label brands. Australasian Marketing Journal, 19(1), 30-39.

Yongchang, C., Hong, X., \& Jing, G. (2011). An integrated framework of tour guide interaction quality, tourist perceived risk and satisfaction. Paper presented at the 8th International Conference on Service Systems and Service Management (ICSSSM), Tianjin, China.

Yoon, S., \& Lee, C.-K. (2014). Examining th Relationships among the Crowding, Perceived Risk, Satisfaction, Trust, and Support in a Festival Site: The Case of the Seoul Lantern Festival. Journal of Hospitality and Tourism Studies, 16(6), 337-357. 